\title{
STUDY OF DIFFERENT TREATMENT MODALITIES AND OUTCOME IN PRETERM BABIES WITH RESPIRATORY DISTRESS SYNDROME
}

\author{
Deepa Sachin Phirke1, Sudhakar Bantewad², Swati Khot ${ }^{3}$ \\ ${ }^{1}$ Associate Professor, Department of Paediatrics, Government Medical College, Miraj, Maharashtra. \\ ${ }^{2}$ Assistant Professor, Department of Paediatrics, Government Medical College, Miraj, Maharashtra. \\ ${ }^{3}$ Assistant Professor, Department of Paediatrics, Government Medical College, Miraj, Maharashtra.
}

\section{ABSTRACT}

\section{BACKGROUND}

Hyaline membrane disease (HMD) is the commonest cause of respiratory distress among preterm newborn babies. The term HMD is often used synonymously with RDS. The current incidence of HMD in our country is $10-15 / 1000$ live births and in preterm babies is $10 \%-15 \%{ }^{2}$. The primary cause of RDS is inadequate pulmonary surfactant. The manifestations of the disease are caused by the consequent diffuse alveolar atelectasis, oedema and cell injury.

\section{MATERIALS AND METHODS}

It is a prospective, observational study of respiratory distress syndrome in preterm babies admitted in NICU at tertiary care hospital from November 2013 to November 2015. Total 150 babies as per the inclusion and exclusion criteria were included in the study. Detailed history and clinical findings were collected in the predesigned proforma. This data was further analysed using descriptive statistics. The statistical software namely SPSS 21, Chi-square test was used for the analysis of the data and Microsoft Word and Excel have been used to generate graphs and tables, etc.

\section{RESULTS}

It was found that majority of babies were 32 - 34 weeks of gestation. Of the 146 babies who received antenatal steroids, 117 survived and 29 died. While all 4 who did not receive antenatal steroids died. Surfactant was given to 86 babies, of which 76 babies received within $10 \mathrm{hrs}$. Out of 63 babies who did not receive surfactant, 41 survived and 23 died. Amongst the 41 babies who received only CPAP as treatment, all survived. Out of the 76 babies who received Surfactant within 10 hrs. and CPAP, 75 survived and 1 died; 10 babies who received surfactant after $10 \mathrm{hrs}$. and ventilator care only 2 survived and 8 died. Amongst 23 babies who only received ventilator care, all died. The co-morbidities in the form of IVH, PDA, pulmonary haemorrhage, pneumothorax, neonatal sepsis and NEC were seen in $54 \%$ of babies. Neonatal sepsis was seen in $14.6 \%$ of babies.

\section{CONCLUSION}

DS was more common in babies with 32 - 34 weeks gestation. Antenatal steroids and surfactant definitely improved the survival rate in preterm babies with RDS. CPAP is simple and effective means of primary respiratory support for management of mild grade RDS. Early administration of surfactant reduced the need for ventilator care and also the mortality. Neonatal sepsis was the commonest comorbidity associated.

\section{KEYWORDS}

RDS, HMD, Surfactant.

HOW TO CITE THIS ARTICLE: Phirke DS, Bantewad S, Khot S. Study of different treatment modalities and outcome in preterm babies with respiratory distress syndrome. J. Evolution Med. Dent. Sci. 2017;6(72):5113-5116, DOI: 10.14260/jemds/2017/1111

\section{BACKGROUND}

Hyaline membrane disease (HMD) is the commonest cause of respiratory distress among preterm newborn babies. The term HMD is often used synonymously with RDS. The primary cause of Respiratory Distress Syndrome (RDS) is inadequate pulmonary surfactant. The manifestations of the disease are caused by the consequent diffuse alveolar atelectasis, oedema and cell injury. ${ }^{1}$ The current incidence of HMD in our country is $10-15 / 1000$ live births and in preterm babies is $10-15 \% .^{2}$

Financial or Other, Competing Interest: None.

Submission 30-07-2017, Peer Review 23-08-2017,

Acceptance 30-08-2017, Published 07-09-2017.

Corresponding Author:

Dr. Swati Khot,

'Girnar' Plot no 55, K.N.P Housing Society,

Vijaynagar, Sangli.

Maharashtra,

E-mail: swati.madake@gmail.com

DOI: $10.14260 /$ jemds/2017/1111

\section{(c) $($ ) $९$}

The incidence of HMD is highest below 28 weeks $(68$ $80 \%$ ), between 32 - 36 weeks it drops to $15-30 \%$ and in term neonates it is less than $1 \% .^{3,4}$ The radiological and pathological description of RDS was given by Peterson et al in 1961.5 Discovery of surfactant was a major milestone in the aetiology of RDS. It is complex mixture of lipids and proteins that lowers alveolar surface tension. The lipid is mainly dipalmitoylphosphatidylcholine (lecithin- 65\%), phosphatidylglycerol, apoproteins (5\%) and cholesterol. The proteins include SP A, B, C and D, out of which SP-B and SP-C are hydrophobic proteins and SP-A and SP-D are hydrophilic proteins. The hydrophobic and hydrophilic properties of the phospholipids cause head to tail orientation in the air-liquid interface inside the alveolus, hence they lower the surface tension of the liquid lining of the alveoli and decrease the pressure needed to keep the alveoli open and inflated.6-8 The manifestations of HMD are caused by the consequences of diffuse alveolar atelectasis, oedema and cell injury. ${ }^{1}$ Infants with HMD are almost always premature and cyanotic on room air. There is rapid or laboured breathing beginning 
immediately after birth. The severity of respiratory distress can be assessed by the Silverman Anderson Score.

\section{Mild RDS}

Intercostal retractions are minimum; grunting is intermittent, oxygen requirement $<40 \%$, slight/absent hypercarbia.

\section{Severe RDS}

Prominent retractions, grunting severe, cyanosis apparent soon after birth, oxygen requirement $>60 \%$, respiratory failure, acidosis, hypercarbia, require mechanical ventilation.

On CXR diffuse fine granular densities that develop during first 6 hours of life, more marked at lung bases than at apices are characteristic.9,10 Apart from the clinical suspicion and radiology tests such as amniotic fluid $\mathrm{L} / \mathrm{S}$ ratio and phosphatidylglycerol assessment have been used for the diagnosis. ${ }^{5}$ The Gastric Shake test has been a useful bedside screening test to assess the risk of development of RDS.

Antenatal corticosteroids should be given to pregnant women of 24 to 34 weeks gestation with intact membranes or with preterm rupture of membranes without chorioamnionitis who are at high risk for preterm delivery within the next 7 days to prevent RDS. Steroids accelerate development of type 1 and type 2 pneumocytes, leading to structural and biochemical changes that improve both lung mechanics (maximal lung volume, compliance) and gas exchange. ${ }^{11-15}$

Continuous positive airway pressure has now emerged as a modality of choice for initial management. CPAP may also help reduce ventilator-induced injury and other morbidities as well as decreased hospital stay. ${ }^{16-18}$

Surfactant replacement has been shown to be successful in ameliorating HMD. Surfactant preparations are delivered through the endotracheal tube either within minutes of birth (Prophylactic treatment) or after the symptoms and signs of HMD are present (Selective or "rescue" treatment). Surfactants of human, bovine or porcine origin and synthetic preparations have been studied. The goals of mechanical ventilation are to improve oxygenation and elimination of carbon dioxide without causing pulmonary barotraumas or oxygen toxicity.

The co-morbidities seen in these babies are Pneumothorax, PDA and IVH, pulmonary haemorrhage, necrotising enterocolitis and neonatal sepsis.

\section{MATERIALS AND METHODS}

It was a prospective observational study of respiratory distress syndrome in 150 preterm babies admitted in NICU at tertiary care hospital from November 2013 to November 2015.

\section{Inclusion Criteria}

Inborn and outborn preterm babies whose gestational age of $<37$ wks. at tertiary care hospital NICU, during study period and diagnosed as RDS as per clinical and investigational guidelines.

\section{Exclusion Criteria}

Preterm babies with meconium aspiration, congenital pneumonia, congenital anomalies like choanal atresia, tracheo-oesophageal fistula and diaphragmatic hernia. Informed consent was obtained from the parents and study protocol was approved by the Institutional Ethical Committee. On clinical examination, RR $>60 / \mathrm{min}$ for $>2$ hours, grunting, flaring of nasal alae, subcostal, intercostals retractions, diffuse reticulogranular pattern and air bronchogram on X-ray chest, arterial blood gas done whenever necessary was done and all preterms $<37$ wks. fulfilling the inclusion criteria were included. Treatment modality was decided according to severity of RDS and Silverman Anderson score (Oxygen inhalation, CPAP, Surfactant, Ventilator) and patients were evaluated for complications like Intraventricular haemorrhage, Pulmonary haemorrhage, Patent ductus arteriosus, Pneumothorax, Sepsis and NEC. Mortality in these babies were assessed.

Data was analysed using the statistical software Microsoft Word and Excel, SPSS 21, Primer of biostatistics, and Chisquare test was used to test the level of significance. $P$ value of less than 0.05 (within confidence limit of 95\%) was used to assess the statistical significance.

\section{RESULTS}

\begin{tabular}{|l|l|c|c|c|}
\hline $\begin{array}{c}\text { Gestational } \\
\text { Age }\end{array}$ & Male & Female & Total & Percentage \\
\hline 28-30 wks. & 11 & 6 & 17 & 11.33 \\
\hline $30-32$ wks. & 21 & 7 & 28 & 18.66 \\
\hline $32-34$ wks. & 39 & 40 & 79 & 52.66 \\
\hline $34-36$ wks. & 18 & 8 & 26 & 17.33 \\
\hline
\end{tabular}

Table I. Distribution of Neonates as per Gestational Age

\begin{tabular}{|c|c|c|c|}
\hline $\begin{array}{c}\text { Antenatal } \\
\text { Steroid }\end{array}$ & Discharge & Death & Total \\
\hline Given & 117 & 29 & 146 \\
\hline Not given & 00 & 4 & 4 \\
\hline \multicolumn{2}{|c|}{ Table II. Effect of Antenatal Steroid and Outcome } \\
\hline
\end{tabular}

According to Yate's correction Chi-sq. 3.103, $\mathrm{P}=0.007$ significant. In this $2 \times 2$ table, more than $20 \%$ cell count is less than 5. So, Chi-square could not be applied, Chi-square was applied after Yate's correction.

\begin{tabular}{|c|c|c|c|}
\hline Surfactant & Discharge & Death & Total \\
\hline Given & 76 & 10 & 86 \\
\hline Not given & 41 & 23 & 64 \\
\hline Total & $\mathbf{1 1 7}$ & $\mathbf{3 3}$ & $\mathbf{1 5 0}$ \\
\hline \multicolumn{3}{|c|}{ Table III. Effect of Surfactant and Outcome } \\
\hline
\end{tabular}

Chi-sq.= 11.99, $\mathrm{P}$ Value $=0.001$ was significant .

\begin{tabular}{|c|c|c|c|}
\hline Parameters & Discharge & Death & Total \\
\hline $\begin{array}{c}\text { Antenatal } \\
\text { steroid } \\
\text { received }\end{array}$ & 117 & 29 & 146 \\
\hline $\begin{array}{c}\text { Surfactant } \\
\text { given }\end{array}$ & 76 & 10 & 86 \\
\hline $\begin{array}{c}\text { Surfactant not } \\
\text { given }\end{array}$ & 41 & 19 & 60 \\
\hline \multicolumn{2}{|c|}{ Table IV. Effect of Antenatal Steroids and Surfactant } \\
\hline
\end{tabular}

P value 0.007 was significant. 


\begin{tabular}{|c|c|c|}
\hline $\begin{array}{c}\text { Respiratory } \\
\text { Support after } \\
\text { Surfactant }\end{array}$ & $\begin{array}{c}\text { Surfactant } \\
\text { Given }<\mathbf{1 0} \text { hrs. } \\
\text { of Life }\end{array}$ & $\begin{array}{c}\text { Surfactant } \\
\text { Given }>\mathbf{1 0} \text { hrs. } \\
\text { of Life }\end{array}$ \\
\hline CPAP* & 76 & 00 \\
\hline Ventilator & 00 & 10 \\
\hline Discharge & 75 & 02 \\
\hline Death & 01 & 08 \\
\hline Table V. & \multicolumn{2}{|c|}{ respiratory support after Surfactant Therapy } \\
\hline
\end{tabular}

Table V. Respiratory support after Surfactant Therapy

*Continuous positive airway pressure.

\begin{tabular}{|c|c|c|c|c|}
\hline Treatment & CPAP* & $\begin{array}{c}\text { CPAP+ } \\
\text { Surfactant }\end{array}$ & $\begin{array}{c}\text { Surfactant+ } \\
\text { Ventilator }\end{array}$ & Ventilator \\
\hline Discharge & 41 & 75 & 02 & 00 \\
\hline Death & 00 & 01 & 08 & 23 \\
\hline Total & 41 & 76 & 10 & 23 \\
\hline \multicolumn{5}{|c|}{ Table VI. Treatment Modality in RDS } \\
\hline
\end{tabular}

*Continuous positive airway pressure.

Neonates were first classified according to Silverman Anderson score and accordingly given treatment as per score. Neonates with score $<4$ received only CPAP and neonates with score between 4 - 7 were given CPAP and surfactant, neonates with score $>7$ were ventilated and given surfactant. Those babies who were given surfactant after $10 \mathrm{hrs}$. required ventilation and average duration of ventilation was 3 to 4 days, and those who received only ventilation duration of about $>10$ days, so $100 \%$ mortality.

\begin{tabular}{|c|c|c|}
\hline Morbidity & N & \% \\
\hline Sepsis & 22 & 14.66 \\
\hline $\begin{array}{c}\text { Intraventricular } \\
\text { haemorrhage }\end{array}$ & 5 & 3.33 \\
\hline $\begin{array}{c}\text { Patent ductus } \\
\text { arteriosus }\end{array}$ & 21 & 14 \\
\hline $\begin{array}{c}\text { Pulmonary } \\
\text { haemorrhage }\end{array}$ & 8 & 5.33 \\
\hline Pneumothorax & 12 & 8 \\
\hline $\begin{array}{c}\text { Necrotising } \\
\text { enterocolitis }\end{array}$ & 13 & 8.66 \\
\hline Table VII. Morbidity in Hyaline Membrane Disease \\
\hline
\end{tabular}

Sepsis was the commonest co-morbidity followed by patent ductus arteriosus.

\begin{tabular}{|c|c|c|}
\hline Outcome & $\mathbf{N}$ & $\mathbf{\%}$ \\
\hline Discharged & 118 & 78.66 \\
\hline Death & 32 & 21.33 \\
\hline Total & $\mathbf{1 5 0}$ & $\mathbf{1 0 0}$ \\
\hline Table VIII. Result of the Outcome in RDS $(\mathbf{n = 1 5 0 )}$ \\
\hline
\end{tabular}

\section{DISCUSSION}

In our study, RDS was more common in $32-34$ wks. gestation. In study done by Urs et al, ${ }^{19} 28$ - 32 wks. were $18 \%$, $30-34$ wks. were $38 \%$ and $>34$ wks. were $6 \%$ and study done by Shrestha ${ }^{20}$ et al 28 - 32 wks. were $34.7 \%, 32-34$ wks. were $65.3 \%$, which was comparable with our study.

There was improved survival in babies who received antenatal corticosteroids. Also, those babies who received antenatal corticosteroids and surfactant had definitely better survival as compared to those who did not.

The survival rate in the babies who received surfactant in our study was $89 \%$ (77/86), while in other studies of Hossain et $\mathrm{al}^{21}$ and Narang et $\mathrm{al}^{22}$ it was $70 \%$ and $52 \%$ respectively. The babies who received surfactant within $10 \mathrm{hrs}$. of life improved with CPAP, did not require ventilator care and had good survival rates.

In our study, out of 150 babies 41 (27\%) babies received CPAP whose weight was $1-1.5 \mathrm{~kg}$ and maturity was in between 32 - 34 wks. gestation showed that it was effective treatment and all are discharged. According to Prashanth $\mathrm{S}$ $\mathrm{Urs}^{18}$ et al, bubble CPAP- a primary respiratory support for RDS showed that CPAP effective in 40 (80\%) out of 50 babies, hence CPAP is simple and effective means of primary respiratory support for management of mild grade RDS.

As per the type of respiratory support given after surfactant in our study, $76(87 \%)$ received CPAP and 11 $(13 \%)$ received ventilation as compared to Monir Hossain 22 et al CPAP received 13 (48\%) and ventilation 14 (51.77\%) concluding that surfactant reduces the requirement of ventilation, reduces complications and decreases mortality.

76 babies whose Silverman Anderson score was 4 - 7, received surfactant within 10 hours of life and after surfactant therapy were put on CPAP therapy responded well and 75 babies survived and 10 babies who received surfactant after 10 hours of life failed CPAP and put on mechanical ventilation, out of which 2 survived and 8 died. It showed that delay in surfactant therapy will affect the outcome.

23 babies whose Silverman Anderson score $>7$ were ventilated and who did not receive surfactant due to financial constraint had $100 \%$ mortality and also duration of ventilation was more around 7 - 10 days.

In our study, co-morbidity developed in $54 \%$ cases in the form of pulmonary haemorrhage, intraventricular haemorrhage, PDA, pneumothorax, sepsis or necrotising enterocolitis. Neonatal sepsis was seen in majority of cases (14.6\%).

Mortality rate was $21.6 \%$ (32/150) in our study according to Pradeep M, L Rajam, P Sudevan et al ${ }^{23}$ mortality due to RDS was $15 \%$ which was comparable and also according to report of National Neonatal Perinatal database ${ }^{24}$ mortality due to RDS was $13.5 \%$ which was comparable with our study.

\section{CONCLUSION}

Administration of antenatal steroids in pregnant women during preterm delivery significantly improves lung maturity and is associated with improved condition at birth and reduces the deleterious effect of poor condition at birth on early respiratory morbidity and mortality.

CPAP is safe and effective treatment modality. Early institution of CPAP in management of RDS can significantly reduce the need of mechanical ventilation and if used along with early surfactant there was good recovery with minimum associated complication.

Early use of surfactant improved survival, shortened duration of ventilation, reduced complication and decreased mortality.

Sepsis is an important complication and its presence along with high RDS score at intubation are significant predictors of mortality. 


\section{REFERENCES}

[1] Bhakta KY. Tests for pulmonary surfactant. In: Cloherty JP. edr. Manual of neonatal care. $7^{\text {th }}$ edn. 2011:406-7.

[2] Singh M. Care of the newborn. $7^{\text {th }}$ edn. 2010: p. 283.

[3] Nelson's Textbook of Pediatrics. 19th edn. 2011: p. 581.

[4] Miller HC, Futrakal P. Birthweight, gestational age and sex determining factor in incidence of respiratory distress syndrome of prematurely born infants. J Pediatrics 1968;72:628.

[5] Peterson HG, Pendleton ME. Contrasting roentgenographic pulmonary patterns of HMD. Am J Roentgenography 1961;74:800.

[6] Clements JA, Platzker A, Tierney DF, et al. Assessment of the risk of the RDS by a rapid test for surfactant in amniotic fluid. N Engl J Med 1972;286(20):1077-81.

[7] Avery ME. Lung disorders in newborn infants. $6^{\text {th }}$ edn. Philadelphia: WB Saunders \& Co., 2005:557-62.

[8] Carlo WA, Namasivayam A. Nelson Textbook of Pediatrics. 2007.

[9] Avery ME, Fletcher BD. The lung and its disorders in the newborn. Philadelphia: WB Saunders \& Co., 1974: p. 119.

[10] Forfar A. Textbook of Pediatrics. $7^{\text {th }}$ edn. 2008:177-8.

[11] Smolders-de Haas H, Neuvel J, Schmand B, et al. Physical development and medical history of children who were treated antenatally with corticosteroids to prevent respiratory distress syndrome: a 10- to 12year follow-up. Pediatrics 1990;86(1):65-70.

[12] Ballard PL, Ballard RA. Scientific basis and therapeutic regimens for use of antenatal glucocorticoids. Am J Obstet Gynecol 1995;173(1):254-62.

[13] Ballard PL. Hormonal regulation of surfactant in fetal life. Mead Johnson Symp Perinat Dev Med 1978;14:25-39.
[14] Walther FJ, David-Cu R, Mehta EL, et al. Higher lung antioxidant enzyme activity persists after single dose of corticosteroids in preterm lambs. Am J Physiol 1996;271(2 Pt 1):L187-91.

[15] Polk DH, Ikegami M, Jobe AH, et al. Preterm lung function after retreatment with antenatal betamethasone in preterm lambs. Am J Obstet Gynecol 1997;176(2):308-15.

[16] Gregory GA, Kitterman JA, Phibbs RH, et al. Treatment of the idiopathic respiratory distress syndrome with continuous positive airway pressure. N Engl J Med 1971;284(24):1333-40.

[17] Polin RA, Sahni R. Newer experience with CPAP. Semin Neonatal 2002;7(5):379-89.

[18] JeyaBalaji RV, Rajiv PK, Patel VK, et al. Outcome of early CPAP in the management of RDS in premature babies with $<32$ weeks of gestation. Indian Journal of Neonatal Medicine and Research 2015;3(2):1-6.

[19] Urs PS, Khan F, Maiya PP. Bubble CPAP - a primary respiratory support for respiratory distress syndrome in newborns. Indian Pediatrics 2009;46(5):409-11.

[20] Shrestha S, Dangol SS, Shrestha M, et al. Outcome of preterm babies and associated risk factors in a hospital. J Nepal Med Assoc 2010;50(189):286-90.

[21] Hossain MM, Shirin M, Akter S, et al. Surfactant replacement therapy for RDS-experience of a NICU of private set-up. DS (Child) H J 2010;26(2):76-81.

[22] Narang A, Kumar P, Dutta S, et al. Surfactant therapy for hyaline membrane disease: the Chandigarh experience. Indian Pediatr 2001;38(6):640-6.

[23] Pradeep M, Rajam L, Sudevan P. Perinatal mortality-a hospital based study. Indian Pediatric 1995;32(10):1091-4.

[24] National Neonatal Perinatal Database. Report for the year 2002-03.

http://www.newbornwhocc.org/pdf/nnpd_report_2 002-03.pdf 